\title{
AN ANALYSIS OF THE COOPERATIVE MAXIMS IN THE "OMAR" MOVIE
}

\author{
Suswanto Ismadi Megah ${ }^{1}$, Kenthik Dwi Wahyuni ${ }^{2}$ \\ English Department, Teacher Training and Education Faculty, University of Riau Kepulauan, Batam, \\ Indonesia \\ Email:megah76@yahoo.co.id ${ }^{l}$,kenthik.wahyuni@gamil.com ${ }^{2}$
}

\begin{abstract}
This study was aimed to analyze types of cooperative maxims in the" Omar" movie. In addition, this study could be considered as a language is a complex phenomenon whose meaning depends on where and when it is used in the "Omar"movie based on the interrogation between the Israeli soldier and the main character (Omar). This study used cooperative maxims of Grice's theory that The cooperative principle was stated in the following way make your conversational contribution such as was required, at the stage at which it occurs, by the accepted purpose or direction of the talk exchange in which you were engaged. This study applied descriptive qualitative approach in analyzing of the data obtained. The data based on the transcription of the dialogue of the main character and the Israeli soldier. The data found was the maxim of quantity $16 \%$, maxim of quality 5\%, maxim of relevant $47 \%$, and maxim of manner $32 \%$. Therefore, in this study the most dominant was relevant maxims. Thus, the most frequently used was relevant maxims because the interrogation needed relevant to answer the interogerator.
\end{abstract}

Keywords: analysis, cooperative maxims and Omar movie.

\section{INTRODUCTION}

Communication is unavoidable part in human life. Therefore, someone can make himself do not feel isolated from the surrounding environment, communication is important in our daily life, because communication is useful for delivery of messages to others causing a purpose of understanding one another. Baskaran (2005:2) then explains that communication is a wide ranging term, but the context of human communication. Hence, communication also important in the establishment of inter-human relationships, and in the formation of a person's character and personality, because by using communication the human can shape the experiences that a person can develop. In addition, in addition Nunan (1993: 8) that communication can be divided into two types, namely communication in the spoken 
or written form. Spoken form is delivered message verbally to others. While, written form is used to communicate with others who are changed in specific time and space, or for those occasions on which permanent or semi-permanent record is required.

Theory applied linguistics is a branch of linguistics that focuses on general theory and methods common in the study of language. Chaer (2009:3) states that, linguistics means the study of using a language as an object of the study. So linguistics is knowledge about language. In general linguistics is the search for knowledge that people have about the language, an understanding of the structure of language and knowledge of how different languages to each other. Linguistics consists of syntax, sociolinguistics, semantics, pragmatics, etc. Leech states pragmatics is study of the relationships between linguistic forms and the users of those forms. So in a pragmatic, human can become the main object to analysis, example greeting someone.

The cooperative maxim can be seen in the "Omar"movie, because in the "Omar"movie many use the type of cooperative maxim. Two state conflict between Israelis and Palestinians resulted in misery and suffering among citizens to establish good relations between the two sides either in a relationship, friendship or talking all constrained. The existence of the phenomenon of political conflict and endless between the two sides resulted the writers are encouraged to analyze cooperative maxim, because the cooperative maxim can prevent or mitigate conflict on both sides.

\section{UNDERLYING THEORY}

\section{a. Pragmatics}

According to Leech (1983:1), the subject of 'pragmatics' is very familiar in linguistics today. Fifteen years ago it was mentioned by linguistics rarely, if at all. In those faroff-seeming days, pragmatics tended to be treated as rag-bag into which recalcitrant data could be conveniently stuffed, and where it could be equally conveniently forgotten. In addition, According to Meyer (2009:48), pragmatics explores the role that context plays in the interpretation of what people say. It means people need to understand the entire social context in which a sentence was uttered. While Mey (2001: 42) defines, pragmatics is the study of the conditions of human language uses as these are determined by the context of society. 
In addition, Yule (1996:3), this perspective then raises the question of what determines the choice between the said and the unsaid. The basic answer is tied to the notion of distance. Closeness, whether it is physical, social, or conceptual, implies shared experience. On the assumption of how close or distant the listener is, speaker determines how much needs to be said. Pragmatics is the study of the expression of relative distance.

Speech will be good if the speaker and the person said to obey the principles of cooperation or pragmatic principles. Maxim is a principle of inquiry that is binding on his nominalist opponents. Maxim is based on his theory of cognitive signs or symbols. In that sense a maxim is a thought that can motivate individuals.

The utterance will be relevant with the contexts, clear, easy to be understand, concise, and always straight forward, and will not waste the time. In every conversation, people should make a good cooperation with others. Grice has principle to the conversation will be good, relevant with the contexts, clear, and easy to be understand. Speech will be good if the speaker and the person said to obey the principles of cooperation or pragmatic principles called maxims. There are kinds of general principles of pragmatics.

\section{b. Cooperative Maxims}

In social communication, people have a tool to communicate as social activities. According to Grice (1975) in Grundy (2000:72), the speakers intend to be cooperative when they talk. One way of being cooperative is for a speaker to give as much information as is expected. The activities of other social, language activities materialized only when humans are involved in it. In the talk, the speaker and said opponents are equally aware that there are rules that govern its actions, the use of language, and interpretation-to interpretation of the actions and sayings of the opponent he said. Each participant is responsible for the speech act and the act of deviation from the rules of the language in the lingual interaction.

Furthermore, Mey (2001:72), states that cooperation has itself been elevated to the status of an independent principle it the works of the late British / American philosopher H. Paul Grice $(1975,1989)$. Whose Cooperative Principle (abbreviated: 
$\mathrm{CP}$ ) consists of four pragmatics sub principles.An account as an explanation of certain features of conversations, it can be extended in obvious ways to other communicative situations.

It is to carry out the work principle, each speaker must adhere to four maxims of conversation (conversational maxim), the maxim of quantity (the maxim of quantity), the maxim of quality (maxim of quality), maxims relevansi (maxim of relevance), and maxims implementation (the maxim of Manner).

\section{1) Maxim of Quantity}

The maxim of quantity, where one tries to be as informative as one possibly can, and gives as much information as is needed, and no more. Maxim of quantity requires each participant sub situation contribute to taste or as much as needed by the interlocutor.

According to Grice (1975) in Yule (2010:147), The Quantity maxim is make your contribution as informative as is required, but not more, or less, than is required. The maxim of quantity is concerned with amount of information (taken in its broadest sense) an utterance conveys. In maxim quantity don't say too much; don't say too little.

\section{2) Maxim of Quality}

The maxim of quality, where one tries to be truthful, and does not give information that is false or that is not supported by evidence. With the quality maxim, if the speaker asks for something then the hearer must only respond with an answer that is truthful. The hearer must not say what she/he is not sure of.

\section{3) Maxim of Relation}

The maxim of relation, where one tries to be relevant, and says things that are pertinent to the discussion. Maxim of relation is very simple: Be relevant.According to Grice (1975) in Yule (2010:147), the Relation maxim: Be relevant, the point of this maxim is that not sufficient for a statement to be true for it to constitute an acceptable conversational contribution. In maxim of relation is stay on topic; don't digress.

\section{4) Maxim of Manner}

The maxim of manner, when one tries to be as clear, as brief, and as orderly as one can in what one says, and where one avoids obscurity and ambiguity. According to Grice (1975) in Yule (2010:147), the Manner maxim: Be clear, brief and orderly. In 
the maxim of manner is make sure what you say is clear and unambiguous. Grice (1975) in Yule (1996:37), states that the maxim of manner has four components. There are:
a) Avoid obscurity of expression.
b) Avoid ambiguity
c) Be brief (avoid unnecessary prolixity).
d) Be orderly.

\section{c. Synopsis of the "Omar"movie}

"Omar" is a 2013 Palestinian drama film directed by Hany Abu-Assad. It was screened in the UN certain regard section at the 2013 Cannes Film Festival. Where it won the Special Jury Prize.It was shown at the 2013 Toronto International Film Festival. The film has been selected as the Palestinian entry for the Best Foreign Langauge Film at the $86^{\text {th }}$ Academy Award, and was among the five finalists. It also won Best Feature Film at the 2013 Asia Pacific Screen. The film was screened at the United Nations in New York on 1 May 2014. The drama, the story of three childhood friends and young woman who are torn apart in their fight for freedom, is billed as the first fully financed film to come out of the Palestinian cinema industry.

\section{METHODOLOGY}

The research design is one of the most important part in a research. There are some approaches in doing research. According to Cresswell (2003:18), there are three approaches to research are quantitative approach, qualitative approach and mixed methods approach. Therefore, this study uses qualitative. While Arikunto (1998:291) states that a descriptive research is not used to test the hypothesis but only to describe what is being seen, faced, observed and known. In this study, the writer used descriptive qualitative approach when analyze the data. In this study, the writer had done with two types in collecting the data. There are two types of the research data in this study. Primary data source was the the script of the movie "Omar", and secondary data sources were from some books of linguistics, pragmatics, etc. In data analysis, the writer will differents type of maxims and then the writer will examine every data 
based on the main characters of the "Omar movie". To analyze the data, the writer will use steps. There are steps to analyze the data "Omar" movie scripts. From collecting data until data analyzed and the data concluded.

\section{DATA FINDING}

In this chapter consists of the data finding and discussion. The data finding is done based on the formulation of the study. The writer analyze the data based on Cooperative Maxims of the "Omar"movie. The data are selected by the writer to answer the formulation of the study in the chapter I by using cooperative maxims in the chapter II. As the next part, the data finding of the data and discussion of the data are done which is followed by:

\section{a. Finding of the Data}

The finding of the data is the data found totally. The data of this study was obtained from the "Omar"movie. The data analyzed by using Grice (1975) theory of Maxims. Therefore this part is the data display based on the percentage of the frequenly occurred in the "Omar"movie. The data can be shown as follows:

Table 1. The Percentage of the Data Finding

\begin{tabular}{lcc}
\hline Maxims Grice (1975) theory & Frequency & Percentage \\
\hline Maxim of Quantity & 22 & $16 \%$ \\
Maxim of Quality & 7 & $5 \%$ \\
Maxim of Relevant & 65 & $47 \%$ \\
Maxim of Manner & 44 & $32 \%$ \\
\hline Total & 138 & $100 \%$ \\
\hline
\end{tabular}

It based on the table above that the maxim of quantity $16 \%$, maxim of quality $5 \%$, maxim of relevant $47 \%$, and maxim of manner $32 \%$. So maxims theory used in the analysis of the cooperative maxims in the "Omar "movie. The most frequently in the "Omar"movie used Relevant maxims. 


\section{b. Discussion}

This based on the table 1, the data faund can be discussed based the maxims theory and focus on Cooperative Maxims. There are maxims of quantity, maxims of quality, maxims of relevant, maxims of manner in "Omar"movie. Those will more detail follows:

\section{1) Maxim of Quantity}

Maxim of quantity is where one tries to be as informative as one possibly can, and gives as is needed, and no more. Maxim of quantity requires each participant sub situation contributed to taste or as much as needed by the interlocutor. This based on the "Omar"movie. This can be seen in following data below:

There 22 data that indicate that the speaker wants to give the information that problem between speaker and a friend is not the business the listener, because the listener knows that the speaker and his friend hostile and listeners want information about the relationship of friendship between them.

\section{2) Maxim Quality}

The maxim of quality, was one tries to be truthful, and does not give information that is false or that is not supported by evidence. With the quality maxim, if the speaker asks for something then the hearer must only respond with an answer that is truthful. The hearer must not say what she/he is not sure of. The maxim of quality is concerned with truth-telling.

There were 7 data which show that the speaker is serious in launching attacks against the Israeli soldier, and the speaker carefully plan to run according to plan and the listener to be able to perform his duties as plan by the speaker. There is relevant speech problem between the speaker and the listener.

\section{3) Maxim of Relevant}

The maxim of relevant, where one tries to be relevant, and says things that are pertinent to the discussion. Maxim of relation is very simple: Be relevant. According to Grice (1975) in Yule (2010:147), the Relation maxim: Be relevant, the point of this maxim is that not sufficient for a statement to be true for it to constitute an acceptable conversational contribution. In maxim of relation is stay on topic; don't digress. 
In this study there were data 65 indicates that the speaker asks the relation of the hearer, in this study between Israeli soldier who interogated the Palestinian prisoner, therefore, the dialogue must be relevant.

\section{4) Maxim of Manner}

Maxim of manner is when one tries to be as clear, as brief, and as orderly as one can it what one says, and where one avoids obscurity and ambiguity. Maxim of manner has four components. There are avoid obscurity of expression, avoid ambiguity, be brief, and be orderly in the communication between the speaker and the listener.

The data found 44 shown that the speaker calls the name of the listener and the listener responses clearly to say "yes?" The speaker wants to know who is the man kill the Israel soldiers? There is conversation between the speaker and the listener very simple, clear and directly.

\section{CONCLUSION}

This study can be concluded that the meaning each utterance contains the Grice maxims used in "Omar" movie. The data found that the maxim of quantity 16 $\%$, maxim of quality $5 \%$, maxim of relevant $47 \%$, and maxim of manner $32 \%$. Hence, maxims theory is used in the analysis of the cooperative maxims in the "Omar "movie. The most frequently in the "Omar"movie used Relevant maxims maxim of relevant $47 \%$, this shows that in communicating between speaker and listener, participants must adhere to the principle of communicating because with the principle of cooperation between the speaker and the listener will be able to avoid misunderstanding. Because good communication is can prevent conflict in the society and the good communication is essential to happen interaction between a person or group of the people to coherent and prevent the conflict.

\section{BIBLIOGRAPHY}

Arikunto, Suharsimi. 1998. ProsedurPenelitian: SuatuPendekatanPraktek. Jakarta. RinekaCipta.

Baskaran, Loga. 2005 Linguistics PrimerFor Malaysia. Kuala Lumpur: Press. 
Chaer, Abdul \&LeoniAgustina. 2009. Sociolinguistics perkenalanAwal. Jakarta: RinekaCipta.

Creswell, J.W. 2003.Research Design Qualitative, Quantitative, And Mixed Methods Approaches.Thousand Oaks. London. New. Delhi.

Fresh.Omar. 2013. Omar. https:// www.Youtube.com / watch.access on Jan25, 2017/13:14

Grundy, P. 2000. Doing Pragmatics. Oxford University Press. Inc. New York.

Jaszczolt, K.M. 2002.Semantics And Pragmatics.Meaning in Language and Discourse.Longman.London.New York. Toronto. Sydney. Tokyo. Singapore. Homg Kong. Cape Town. New Delhi. Madrid. Paris. Amsterdam. Munich. Milan. Stockholm.

Mey, Jacob L. 2001. Pragmatics, An Introduction. Cambridge: Blackwell Inc.

Meyer C.F. 2009.Introducing English Linguistics.Cambridge University Press. Cambridge, New York, Melbourne, Madrid, Cape Town, Singapore,Sao Paulo.

Nunan, David. 1993. Discourse Analysis. England: Clays Ltd.

Yule, George. 1996.Pragmatics. Oxford University Press.

Yule, George.2010.The Study of Language. Cambridge, New York, Melbourne, Madrid, Cape Town, Singapore, Sao Paulo, Delhi, Dubai, Tokyo. 